\title{
Study on the Measures of Teacher Team Construction after the Independent College Transition
}

\author{
Yi ZHU, Qingling LIAO*, Chun LIU, Xiuying WANG, Heai ZENG \\ Wuhan Technology and Business University, Electronic Commerce College, Hubei Wuhan 430065
}

\begin{abstract}
The improvement of scientific research capacity and level is closely related to the construction of the teacher team, the teacher team construction is the core of the independent college construction after transition. This article starts from the importance and urgency of teacher team construction after the independent college transition and analyzes the development status of teacher team and the outstanding problems before independent college transition, and puts forward suggestions on the measures to strengthen teacher team construction after the independent college transition.
\end{abstract}

KEYWORD: Independent college; Transition; Teacher team; Construction

Independent college is mainly composed by private capital that belongs to public welfare, it has met the needs of higher education scale growth and the popularization of higher education. In February 29, 2008, the independent college work conference was held in Beijing. The theme is to implement the measures for the establishment and management of independent college. According to the spirit of the Ministry of Education No.26 order, a group of independent college in the future will gradually turn to private university of independent system, which is not only the macro national policy orientation, but also an inevitable choice for the survival and development of the independent college. The teacher team is the core subject for running a school and the fundamental guarantee [1]. The key competition of education is the competition of teachers, the quality of teacher team determines level of the school, and even the quality and development of the school.

\section{THE STATUS OF TEACHER TEAM AND THE OUTSTANDING PROBLEMS BEFORE INDEPENDENT COLLEGE TRANSITION}

The teacher team in independent college mainly consists of the following three parts: one is the retired teachers, who are retired from teaching and research front line positions in public college, the majority has high education and high professional title; two is the part-time teachers, who are came from public university teachers or enterprises and institutions scientific and technological in-service personnel. this part of teachers has both certain theoretical knowledge and work experience; three is the full-time teachers recruited, who are mainly young teachers with higher education recruiting toward society, this part of teachers is the main body in the independent college, while the society recruited young full-time teachers are insufficient in teaching experience and practice ability.

The retired teachers have rich teaching experience, but their energy is limited and holding and updating of ideas lag is behind the times development. The irrational teachers age structure and the lack of inheritors in subject construction result in the lack of stamina for the development of private college and university. The proportion of part-time teachers is large, but part-time work is not the main job, so they are always in a temporary social psychological state, their occupation expectation and ambition is not necessarily high, who generally have only classroom "preaching" and few spare time "instructing and dispelling doubt", the teaching procedure is not complete. The

Zhu Yi (1977-), male, master, lecturer, Wuhan Technology and Business University, Wuhan 430071, The 2013 scientific research special project (S2013006) : the current situation and countermeasures of the scientific research work of private colleges and universities in Hubei. * Corresponding author 
communication and coordination among teachers is less; which lack continuity and consistency and cannot play the overall function of teaching, so the teaching strategy is superficial. If things go on like this, it will not be able to guarantee high teaching quality. Although part of the schools have relatively stable teacher team, the overall quality and level is not high, and the education, title, age structure and other aspects are irrational. In the current development situation, it is hard to introduce a large number of high level, high degree, and high level talents for independent college, which results to recruit only part of teaching assistants just going out of the campus, and lack young and middle-aged backbone teachers, so that they cannot guarantee the high quality teaching work. On the other hand, the independent college has not formed a teacher cultivating and training mechanism timely and effectively, the reform of the personnel system lags behind, and the establishment and perfection of the appointment, evaluation, and incentive system of teachers lacks certain scientific rationality. This condition brings many unstable factors to the sustainable development of independent colleges.

\section{THE NECESSITY AND URGENCY TO STRENGTHEN THE CONSTRUCTION OF TEACHER TEAM AFTER TRANSITION}

The independent college will gradually transit to private university which is conducive to the development of private higher education and to the scientific position and characteristics development. The teacher team construction is the key orientation of college, and also the core force of the human resources. The times are characterized by knowledge economy with highly developed science and technology that is deeply affecting all aspects of society and full of competition and opportunities. Teachers in college are facing the new century internationalization, high-tech, market competition and other challenges. The construction work of college teacher team is faced with the dual task of transition to market economy and being in line with international standards. Teachers in college are not only the present high-quality human resource but also cultivators to train future high-quality human resources, so research on the construction of college teacher team has become the most urgent problem. Independent college is a new thing of China's higher education system reform. Compared with public college, the management mode of independent college is still not mature and in continuously exploring state, it will face more difficult survival pressure after transition. The teacher team is the core subject of running a school and the fundamental guarantee for the survival and development of college. The key of education competition is the competition of teachers, and the quality of teacher team decides the quality and development of college. After transition, independent college is separated from the central department strong human resources, whether it can have a high-quality and high level of teacher team is the key for the healthy and sustainable development of the independent college after transition, which is the fundamental guarantee to improve the quality of school running and the key to build a strong discipline form its characteristics, and then to create its own brand for an independent college. In view of the problems on the teacher team construction, the problems need to be solved after transition and to reform the existing teaching staff management model, to implement innovative, to open teacher management mode, to emancipate the mind and vision with long-term view and willing to invest, to introduce talent with all efforts, and to establish a capable and stable management team and teacher team. The independent college will have the advantages management system of greater autonomy and flexibility after transition, which is easier to run with distinguishing feature. College should base on the school situation to timely introduce a set of management system with high efficiency, quick decision-making, and strong market adaptability[2] .

\section{THE MEASURES OF TEACHER TEAM CONSTRUCTION}

\subsection{The government needs to introduce and improve the relevant supporting policies}

The teacher team construction in independent college is lagging behind obviously, part of the reason lies in the lack of policies and measures to guide and support. All levels of government and education administrative departments should base on the Document No. 8, and the Minister of Education No. 25 to introduce the relevant supporting policies and measures beneficial to the development of teacher team construction after transition as soon as possible. Independent college need to solve the unequal treatment problems such as the professional titles evaluation and appointment from the laws and regulations and the policy level. It will help to guide public opinion which is form of a good atmosphere in the whole society to care for and support the teacher team construction after transition. 


\subsection{The investment parties in school running need to strengthen the education idea}

The board of directors and the president of the independent college need to hold a high responsible spirit and to handle affairs according to the law of higher education, to formulate scientific planning for the construction teacher team. Private college have little long-term planning for it. They should not only pursuit economic benefits and neglect the teaching quality. There is not stable teacher team and teaching order and quality. The construction of teacher team have been required to create with sufficient good quality and rational structure urgently if the college want to have a certain competitiveness after transition. To speed up the construction of a high level young backbone teacher team is the primary task and fundamental way to improve the teaching strength and to form school characteristics. According to the development plan of the school running scale, independent college should grasp the vacancies situation of teachers in quantity, age structure, education structure and professional title structure. External introduction main refers to introducing attractive policy measures, like diverting a portion of research potential not pure teaching professors and associate professors, hiring part graduate students, and recruitment of a part double teacher type talents with intermediate and above titles from the surrounding enterprises and institutions and other social resources; On the internal training, one is taking effective measures to strengthen the training and actively create conditions to improve their professional level. Such as the implementation of funding, refresher training arrangements, the establishment of the tutorial system and research funds, to encourage young teachers to carry out a wide range of research activities and academic exchanges to shorten the growth period of young teachers. Two is strengthening the dedication and regarding teaching as the main content of moral education, to help them to correctly handle the relationship between learning and teaching and the relationship between personal growth and obedience of the job needs. Three is establishing the appropriate reward and punishment mechanism, such as the establishing Education Fund Award, regularly carry out the outstanding teaching award, encourage teachers actively involved in teaching, constantly improve the academic teaching level through the ways of quantitative assessment, supervision teaching, classroom evaluation contest, experience exchange, and students' evaluation of teaching measures. Four is increasing the input of funds and emotion and deepening the reform of personnel distribution system, caring for teachers in study, work and life, giving positive attention to the professional title evaluation, welfare treatment, personal development, and further education aspects, and providing working conditions and environment for their growth. Teachers can concentrate on the teaching to cultivate talents that can meet the social needs assiduously after transition. Excellent teachers are the backbone supports of the school, which are the backbone on improving teaching quality, highlighting the school characteristics and creation of school brand. The higher recognized degree of students by society, the greater social influence and the more competitive the enrollment, which is more conducive to the healthy development of college.

Finally, the independent college administrators should respect the personality and dignity of teachers and he reasonable needs of teachers; they should believe the teacher's ability. The teachers get fully trust that they will be possible to give full play to the autonomy devoted to work and respect the status and the role of teachers in the teaching management activities and adopt effective and reasonable system to motivate the initiative and enthusiasm of teachers. The administrators should create an atmosphere of respecting teachers to arouse teachers' enthusiasm as far as possible. The harmonious interaction between the teachers and school administrators is form and commit to the development and construction of school.

\subsection{Teachers need to improve their own occupation moral and enhance the cohesion of colleges}

The first task for the independent college after transition is to strengthen virtue cultivation of the teachers. With the development of college, teachers should have a strong sense of professionalism and responsibility and dedication spirit. Teaching reflects the essence of education, to impart knowledge and educate people together is an important principle of teaching, which is also the basic duty of each teacher. In the current condition of socialist market economy, morality is the most important quality of teacher, which is the soul of teachers. Teachers should have a noble sentiment, a correct world outlook and outlook on life, be loyal to the party's education career, with their own personality charm to infected and let the students grow up healthily; they should love the students and be tireless in teaching. Their love of the students is not only reflected in the teaching, but also caring about students in life and thoughts; their self-discipline and model for students are important specifications of 
teachers' morality; their rigorous and meticulous are the performance of teachers' scientific attitude in seeking truth.

Teachers as the main subject to preach knowledge, first of all have to master extensive knowledge, if teachers do not have higher scientific and cultural qualities, they can't bear responsibility to complete the preaching, imparting knowledge and doubts. Therefore, teachers should make efforts to improve their teaching level. In view of the talent cultivation orientation after transition, teachers should study professional courses and have deep understanding of the subject content, master the skills the subject knowledge required, but not stick to conventions, look at problems with the viewpoint of development. They should comply with the scientific development trend and understand the new direction of discipline. They should link theory with practice and explore the new problems in the actual work. They should learn the rules and methods of teaching and grasp the advanced and scientific teaching methods. They should establish the idea of lifelong learning and learn from colleagues around, the Internet and other channels. The students have more competitive in the talent market, the life value is more greater.

Finally, the teachers should also consider the actual difficulties after transition. Private college main rely on school fund-raising and tuition. The early college construction economic investment is difficult to keep up with the development, college can only rely on the tuition and loan to realize capital turnover. Heavy economic burden limits the improvement of teacher's benefits. Only when the development of college is health, standardized and continuing treatment of teachers can continue to improve. Teachers should set up highly collective sense of honor and actively offer advises and suggestions for the development of college. To have sustained and healthy development, college should first ensure the survival question which should make full efforts to find student sources, in order to have great enrollment, to recruit good students and to form a certain scale of the school, so as to have the minimum benefit of school running; Secondly, it requires teachers strengthen students' management and perfect service to ensure the scale effect consolidation, so that the student source is stabilized, then with the quality of teaching and the quality education improving. Teachers will truly love school, which can realize the benign operation of teaching and management; Thirdly, college should concentrate on the long-tern development after the scale efficiency consolidation, the key is the flexible and diversified school running, to firmly establish the awareness of quality as the core, quality of survival, of consolidation, of development, of efficiency, of reputation; of teaching management. The service quality has always being the lifeline of private college. With the high quality of school running, the colleges can set up in the world and have the power to compete with other colleges; finally college should have high aim to keep pace with the times and seek innovation. In order to strive for a first-class, characteristic, and branded college[3], everyone work together for a bigger, better, and stronger college to win certain social status, prestige and reputation. After transition, the majority of teachers should make more efforts to improve the school running level, the scientific research level, discipline construction, and teaching quality.

\section{CONCLUSION}

After transition to ordinary higher school, the college is still shoulder the same task of training talents for the country. The construction and management of teaching staff will be an important factor restricting the development of colleges, it is necessary to put the full-time teacher team construction into the important agenda to ensure and improve the quality of teaching and scientific research ability and level. The three party of the government, the school and the teachers should work together to seek common development, to make the teacher team have a good construction and development after the transition of the independent colleges.

\section{REFERENCES}

[1] Yang Guixia. Policy analysis on the comprehensive, balanced and sustainable development local colleges and universities from the perspective of scientific outlook on development. Education and Occupation, 2010676 (36): 183

[2] Zhang Yang, Zhang Xinmin. Analysis on the problems and countermeasures of independent colleges teacher team construction. Higher Agricultural Education, 2008207(9): $40-42$

[3] Zhang Yungui. On the sustainable development of private colleges and universities. Journal of Hubei Correspondence University, 2009, 22 (4): 1 - 3. 